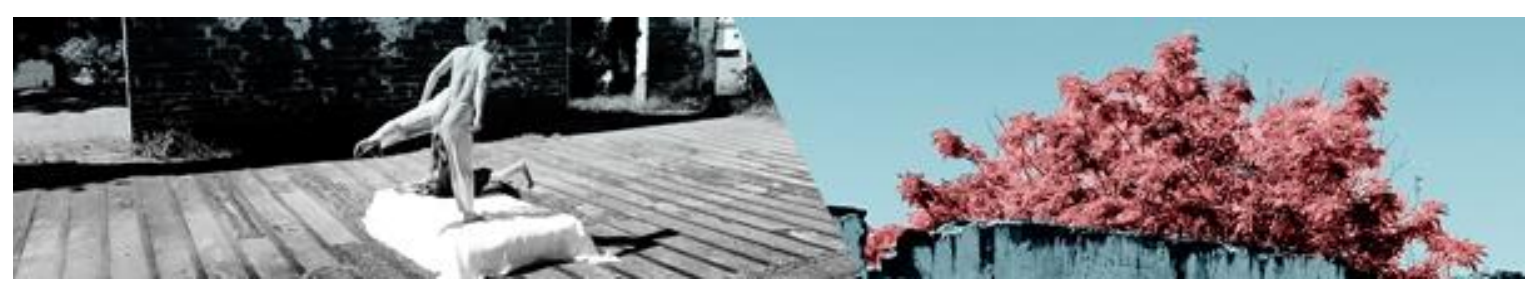

\title{
PINA: QUANDO A DANÇA PODE ROMPER O DISCURSO
}

Rita Bruço1

Resumo: Este artigo propõe uma análise da obra Barba-Azul (1977) de Pina Bausch - considerada a primeira com as características da Tanztheater - e, por meio dela, busca perceber sua linguagem/presença e discurso/materialidade, indicando formas de revelá-las enquanto uma dançateatro própria, numa tessitura que possa permitir outras singularidades. Dialogando com Hans Gumbrecht, Michel Foucault, José Gil, Ciane Fernandes, Katia Canton, entre outros, enfatiza os aspectos da obra que podem ser percebidos em todo o repertório de Pina Bausch a partir de 1977.

Palavras-chave: Pina Bausch; Dança-teatro; Singularidades.

\section{PINA: WHEN DANCE CAN BREAK THE SPEECH}

\begin{abstract}
This article propose an analysis of criation Pina Bausch's Barba-Azul (1977) - considered the first with the characteristics of the Tanztheater - and, through it, seeks to evidence its language/presence and materiality/discourse, indicating ways of revealing them as a itself dancetheater, in a texture that could allows for other singularities. Dialoguing with Hans Gumbrecht, Michel Foucault, José Gil, Ciane Fernandes, Katia Canton, among others, it talks about aspects of the work that can be perceived throughout the repertoire of Pina Bausch from 1977.
\end{abstract}

Keywords: Pina Bausch; Dance-theater; Singularities;

Muitas são as publicações a respeito da produção artística de Pina Bausch, algumas oriundas de extensas pesquisas acerca de aspectos de seu trabalho, articulando-os com outras áreas do saber e conferindo-Ihe o caráter definitivo exponencial do que ela própria denominou de Tanztheater ${ }^{2}$. Neste exercício reflexivo sobre o discurso ${ }^{3}$ de Pina, referenciando um de seus trabalhos, Blaubart. Beim Anhören einer Tonbandaufnahme von Béla Bartóks Oper "Herzog Blaubarts

\footnotetext{
${ }^{1}$ Rita Bruço - Graduanda do Curso de Dança: Licenciatura da Universidade Estadual do Rio Grande do Sul - UERGS. Bailarina-intérprete, coreógrafa, professora-artista e fotógrafa.

2 Tanztheater, neste texto, será referido como dança-teatro, intencionalmente mantendo o hífen seguindo a regra gramatical vigente, pretendendo ressaltar que, como resultado da união dos compostos formados por substantivo + substantivo, obtém-se um novo composto, com sentido único. 3 Discurso, no presente artigo, sob a perspectiva foucaultiana em que as relações de poder estão intrinsecamente ligadas ao enunciado.
}

BRUÇO, Rita. Pina: quando a dança pode romper o discurso. Revista da FUNDARTE, Montenegro, p.340-357, ano 19, ํo 37, Janeiro/Março.

Disponível em: http://.seer.fundarte.rs.gov.br/index.php/RevistadaFundarte/index> 30 de março de 2019. 


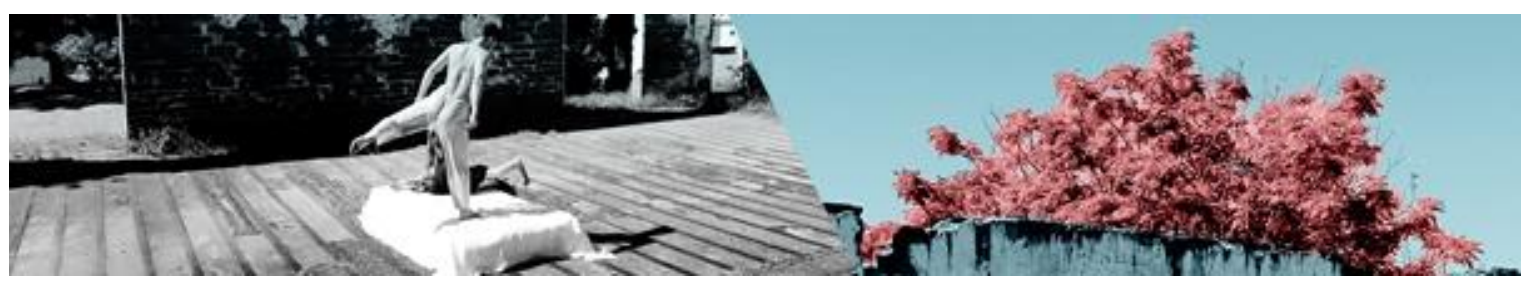

Burg"y/Barba-Azul (1977), o olhar será direcionado sobre a prática discursiva desta obra, examinando e relacionando determinados pressupostos da sua linguagem, percebendo que tal tarefa é o que pode singularizar o trabalho em dança-teatro, uma vez que o processo criativo de Pina esteve irremediavelmente ligado às subjetividades de seu contexto.

Ciane Fernandes (2007, p. 28) traz a seguinte descrição ao tecer considerações estéticas da dança-teatro de Pina:

Nas obras de Bausch, dança e teatro são trazidas ao palco como linguagem, mas não como uma totalidade de corpo-mente ou formaconteúdo. Ao contrário, a natureza linguística daquelas artes é explorada como intrinsicamente fragmentada. Através da fragmentação e da repetição, seus trabalhos expõem e exploram a lacuna entre a dança e o teatro, a nível estético, psicológico e social: movimentos não completam palavras em busca de uma comunicação mais completa; o corpo não completa a mente em busca de um ser total ou de uma maior presença no palco. (grifo nosso).

A despeito de Sparshott ${ }^{5}$ (1995) ter recusado à dança, o estatuto de uma linguagem elencando razões para tanto, autores da dança que não referendam esta linha teórica ainda se utilizam do termo "linguagem", principalmente quando referemse ao trabalho de Pina, seja para identificar o limite entre a multiplicidade de narrativas contidas em seu trabalho, seja para tentar comunicar descritivamente a inegável materialidade expressa em suas obras.

\section{DA LINGUAGEM COMO PRESENÇA}

A pós-modernidade produziu inegáveis alterações na forma como nos relacionamos e percebemos o mundo, e destemporalizou o que tínhamos como dado: o presente como consequência de um passado distinto, que possibilitava pensar o futuro aberto a possibilidades. A contemporaneidade trouxe o sentimento

\footnotetext{
${ }^{4}$ Traduzindo: Enquanto ouve uma gravação em fita do "Duque do Castelo do Barba-Azul" de Béla Bartók.

${ }^{5}$ Francis Sparshott (1926): é filósofo e professor inglês, que dentre outras obras, publicou em 1995, $A$ Measured Pace: Toward a Philosophical Understanding of the Arts of Dance, obra que apresenta 18 razões para que a dança não seja considerada como linguagem.
}

BRUÇO, Rita. Pina: quando a dança pode romper o discurso. Revista da FUNDARTE, Montenegro, p.340-357, ano 19, ํo 37, Janeiro/Março.

Disponível em: http://.seer.fundarte.rs.gov.br/index.php/RevistadaFundarte/index> 30 de março de 2019. 


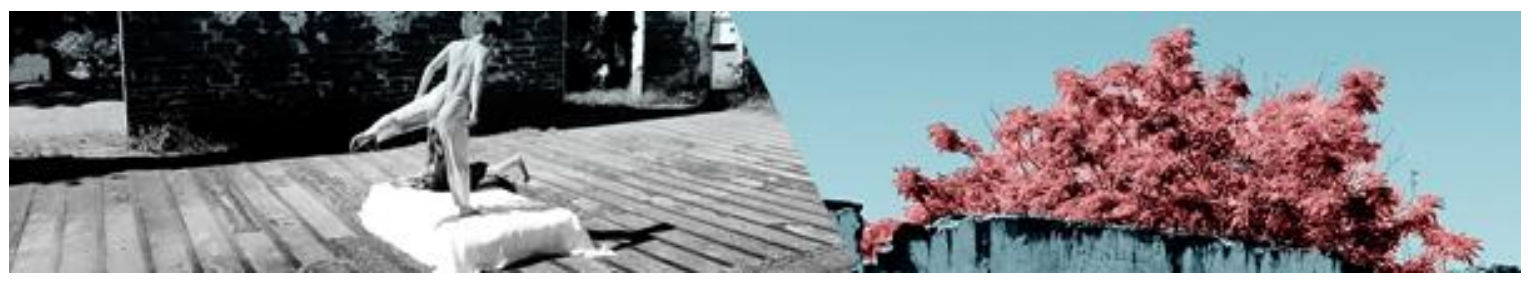

de ameaça ao que está por vir, destotalizando as concepções universais que descreviam o que deveria ser o sujeito, e desnaturalizando sua ação neste mundo, afastando-o do contato com a natureza; a matéria que permitia um referencial seguro do mundo externo, a partir disso, não mais centrado em sua figura. Tais condições levam ao coma da hermenêutica, enquanto campo de premissas centradas no sujeito cartesianamente separado entre corpo e mente, conferindo-lhe o poder de atribuir sentido aos objetos, onde o corpo assumia uma posição secundária e subserviente; um instrumento (GUMBRECHT, 2010). O fracasso em ordenar o mundo e fazê-lo funcionar de acordo com a sua capacidade de ação leva a um campo de análise que possa dar conta de "dizer este mundo" sob outro paradigma. Hans Gumbrecht, também alemão como Pina Bausch, propõe um campo não hermenêutico, problematizando o ato interpretativo agora ausente de uma teoria hegemônica que dê conta de condicioná-lo. Partindo da teoria semiótica de Hjelmslev 6 mapeia a relação de expressão (significante) e conteúdo (significado) e relaciona isoladamente suas divisões: forma da expressão e substância da expressão; e forma do conteúdo e substância do conteúdo. Com isso, propõe a possibilidade de considerar a expressão sem necessariamente associá-la ao conteúdo: [...]não mais procuramos identificar o sentido, para logo resgatá-lo, porém, indagamos as condições de possibilidade de emergência das estruturas de sentido (GUMBRECHT, 2010, p.397).

Destas estruturas, o autor observa o que denomina de culturas de presença (GUMBRECHT, 2009, p.13):

Uma cultura de presença [...]integrará igualmente a existência espiritual e física em sua autorreferência humana [...]os seres humanos se consideram como parte do mundo de objetos ao invés de serem ontologicamente separados dele e [...] buscam apenas inscrever seu comportamento no que consideram ser estruturas e regras de uma determinada cosmologia (chamamos de "rituais" os quadros situacionais para que tais tentativas correspondam a quadros cosmológicos mais amplos). [...]é muito menos

\footnotetext{
${ }^{6}$ Louis Trolle Hjelmslev (1899-1965): foi linguista dinamarquês que, em parceria com Hans Uldall, desenvolveu a teoria semiótica adotada por Ferdinad de Saussure (cujas elaborações teóricas propiciaram o desenvolvimento da linguística enquanto ciência autônoma).
}

BRUÇO, Rita. Pina: quando a dança pode romper o discurso. Revista da FUNDARTE, Montenegro, p.340-357, ano 19, ํo 37, Janeiro/Março.

Disponível em: http://.seer.fundarte.rs.gov.br/index.php/RevistadaFundarte/index> 30 de março de 2019. 


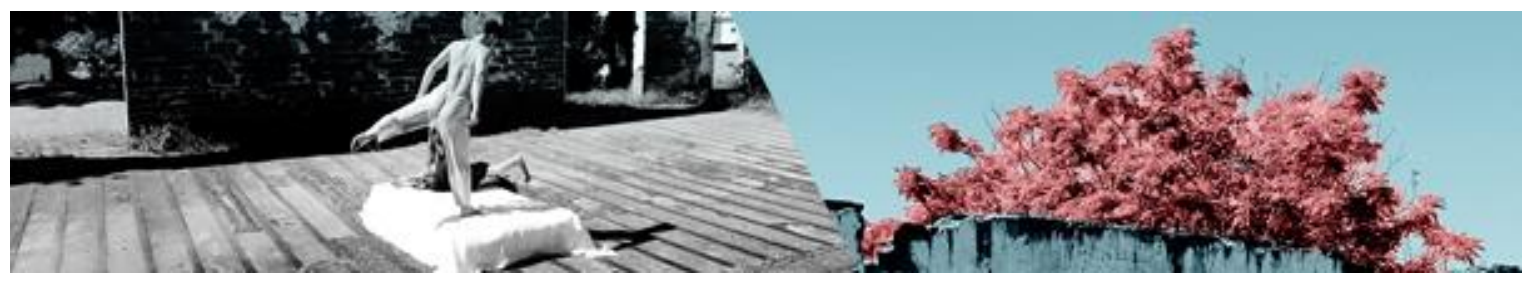

óbvio quais papéis a linguagem pode desempenhar em culturas de presença (ou, ainda, em um mundo visto a partir de uma perspectiva da cultura de presença).

Sob esse aspecto, Hans Gumbrecht elucida algumas ligações que entende possíveis entre linguagem e presença, dentre as quais destacamos a linguagem como uma realidade física que atinge uma forma que precisa ser alcançada, devido ao seu status de objeto no tempo [...]possui um "ritmo" - um ritmo que podemos sentir e identificar independentemente do significado que a linguagem "carrega" (GUMBRECHT, 2009, p.13-14). Como segundo destaque, trazemos a linguagem como experiência estética (GUMBRECHT, 2009, p.15):

[...]Para Luhmann 7 , a comunicação no sistema da arte é uma forma de comunicação na qual a percepção puramente sensória não é apenas uma pressuposição, mas um conteúdo carregado, junto com um sentido, pela linguagem.

Assim balizamos nossa proposição de análise, num campo que possibilite o entendimento da dança-teatro para além do que tem sido dito sobre ela (em narrativas que the conferem sentidos): um lugar de fala, onde a "linguagem" é considerada presença significante, e possibilita a emergência de múltiplas estruturas de significado que permeiam a sua materialidade. Essa materialidade dialoga com o que comenta Ciane Fernandes (2007, p. 30): É através da imagem corporal que $O$ esquema de gestos e posturas de uma sociedade é transmitido. A identidade corporal individual não é autêntica nem contrastante à sociedade. O corpo individual é um corpo social. Um social que reúne, em sua base fundante, as características que moldam e posicionam os sujeitos, conferindo-Ihes identidades e determinando do que são capazes ou não de fazer, por meio de uma materialidade expressa em discurso.

\footnotetext{
7 Niklas Luhmann (1927-1998): foi sociólogo alemão apontado como um dos principais autores das teorias sociais do século $\mathrm{XX}$.
}

BRUÇO, Rita. Pina: quando a dança pode romper o discurso. Revista da FUNDARTE, Montenegro, p.340-357, ano 19, ํo 37, Janeiro/Março.

Disponível em: http://.seer.fundarte.rs.gov.br/index.php/RevistadaFundarte/index> 30 de março de 2019. 


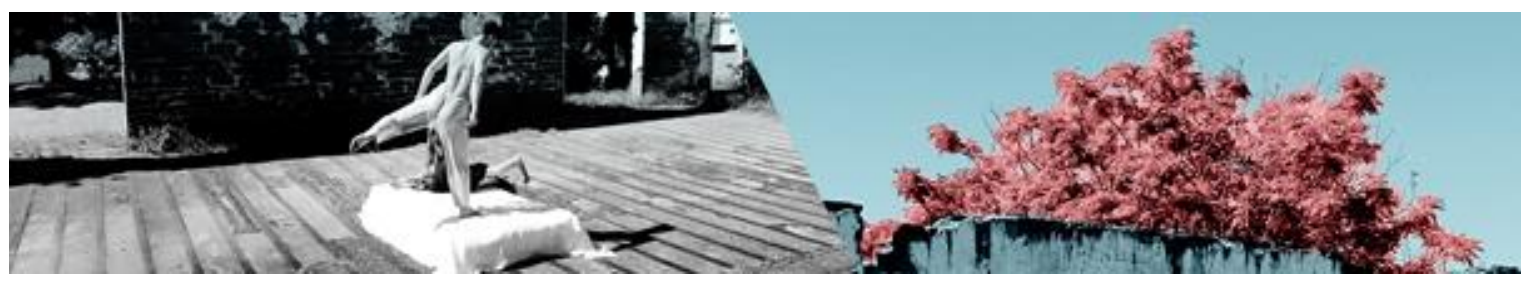

\section{DA MATERIALIDADE COMO DISCURSO}

O discurso levado à potência foucaultiana é aquele que pode ou não legitimar as estruturas de poder existentes, onde a palavra não importa, necessariamente, pelo que é ou faz, mas pelo que diz. E este poder está diretamente relacionado ao conhecimento, na medida em que o valorizamos (o quê?), o distribuímos (como?), e o atribuímos (a quem?).

[...]suponho que, em toda a sociedade, a produção do discurso é ao mesmo tempo controlada, selecionada, organizada e redistribuída por certo número de procedimentos que têm por função conjurar seus poderes e perigos, dominar seu acontecimento aleatório, esquivar sua pesada e temível materialidade. (FOUCAULT, 1999. p. 8-9)

Os engendramentos dos discursos formam aquilo que tomamos como válido, que, em maior ou menor grau, definem aquilo que é permitido ou inaceitável e que, em última análise, tensionam ou mantém o status quo. Cumpre ainda grifar o sentido de autoria dado por Michel Foucault, que considera autor não apenas o produtor de um enunciado, mas o relaciona a outros que o fazem, enquanto agrupamento, sendo capaz de conferir unidade e significações ao formulado, cujo papel desempenha conforme recebe de sua época ou, ainda, conforme for capaz de modificá-lo (FOUCAULT, 1999). No que tange ao que seria uma análise discursiva, trazemos, nas palavras de Foucault (2008, p. 31):

A análise do campo discursivo é orientada de forma inteiramente diferente; trata-se de compreender o enunciado na estreiteza e singularidade de sua situação; de determinar as condições de sua existência, de fixar seus limites da forma mais justa, de estabelecer suas correlações com os outros enunciados a que pode estar ligado, de mostrar que outras formas de enunciação exclui. Não se busca, sob o que está manifesto, a conversa semi-silenciosa de um outro discurso: deve-se mostrar por que não poderia ser outro, como exclui qualquer outro, como ocupa, no meio dos outros e relacionado a eles, um lugar que nenhum outro poderia ocupar. A questão pertinente a uma tal análise poderia ser assim formulada: que singular existência é esta que vem à tona no que se diz e em nenhuma outra parte?

Neste sentido é que propomos uma análise reflexiva sobre a obra de Pina Bausch, entendendo-a como materializada em linguagem enquanto presença de um discurso autoral de criação, que incidiu sobre o tabu da sexualidade, dada em sua

BRUÇO, Rita. Pina: quando a dança pode romper o discurso. Revista da FUNDARTE, Montenegro, p.340-357, ano 19, ํo 37, Janeiro/Março.

Disponível em: http://.seer.fundarte.rs.gov.br/index.php/RevistadaFundarte/index> 30 de março de 2019. 


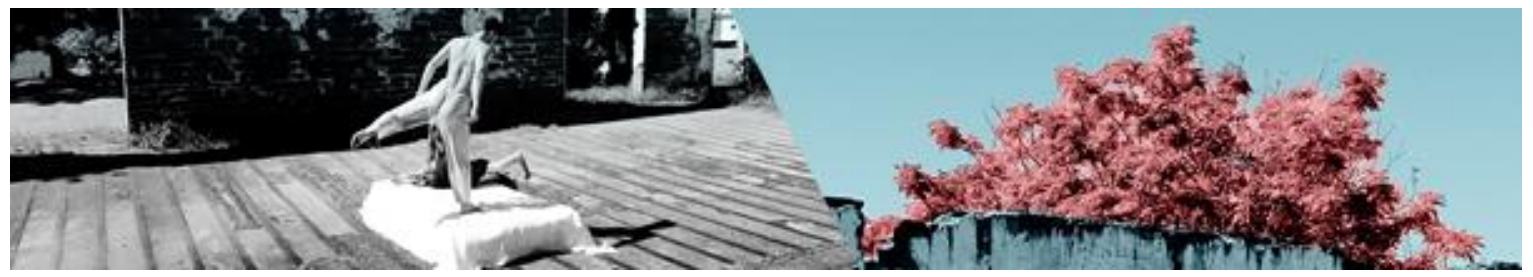

perspectiva mais ampla, como representação de gênero. Afinal, o que está expresso no discurso de Barba-Azul, sob os aspectos de criação trazidos, que tornam a abordagem de gênero singular?

\title{
DA ESTÉTICA E DAS INFLUÊNCIAS DE PINA
}

Antes de abordar diretamente a obra em questão, cumpre dizer sobre alguns aspectos da dança-teatro que reverberam diretamente sobre a sua criação. $O$ itinerário de Pina na dança começa em 1955 com Kurt Jooss ${ }^{8}$, passa pela Julliard School em Nova lorque e retorna para a Alemanha em 1962 como bailarina que, em 1969, começa a coreografar na companhia criada por Jooss. Em 1973 torna-se diretora do Balé da Ópera de Wuppertal, que ela logo renomeou para Tanztheater Wuppertal. Bausch incorpora e altera suas influências. Seus trabalhos incluem a interação entre as diferentes formas de artes como nos Estados Unidos dos anos sessenta, mas de uma forma crítica. (FERNANDES, 2007, p. 23) Pina levava a termo a grandiosidade teatral em figurinos elegantes, bailarinos-intérpretes maquiados e a criação de espaços amplos em suas cenas. Mais do que para ser grandioso, a escolha dos elementos cênicos para Bausch cumpriam outro papel, como nota Ciane Fernandes (2007, p. 24)

\begin{abstract}
Seus figurinos e maquiagem determinam seus papéis sociais e sexuais[...]. A política do corpo não é a de sua provocante nudez interagindo com as outras artes em ambientes extra-palco, como nos anos sessenta. Na dançateatro de Bausch, o corpo estimula a nostalgia por uma Belle Époque e então ridiculariza estes conceitos de beleza a ele impostos. Estereótipos de períodos progressistas como os anos vinte e trinta, personagens hollywoodianos com casacos de vison ou smoking, ou com vestidos rodados dos anos sessenta norte-americanos, são criticamente expostos em estranhos e compulsivos gestos e contextos.
\end{abstract}

Esse contexto, onde gestos da vida cotidiana eram retratados na mesma medida em que um gesto coreografado, demonstra que, tanto na vida, quanto na

\footnotetext{
8 Kurt Jooss (1901-1979): bailarino e coreógrafo alemão que, apesar de ter sido influenciado pelo expressionismo germânico ao qual pertenciam Rudolf Laban e Mary Wigman, foi membro de um movimento subsequente denominado de Neue Sachlichkeit (Nova Objetividade), cujo foco era retratar as realidades sociais de seu tempo.
}

BRUÇO, Rita. Pina: quando a dança pode romper o discurso. Revista da FUNDARTE, Montenegro, p.340-357, ano 19, ํo 37, Janeiro/Março.

Disponível em: http://.seer.fundarte.rs.gov.br/index.php/RevistadaFundarte/index> 30 de março de 2019. 


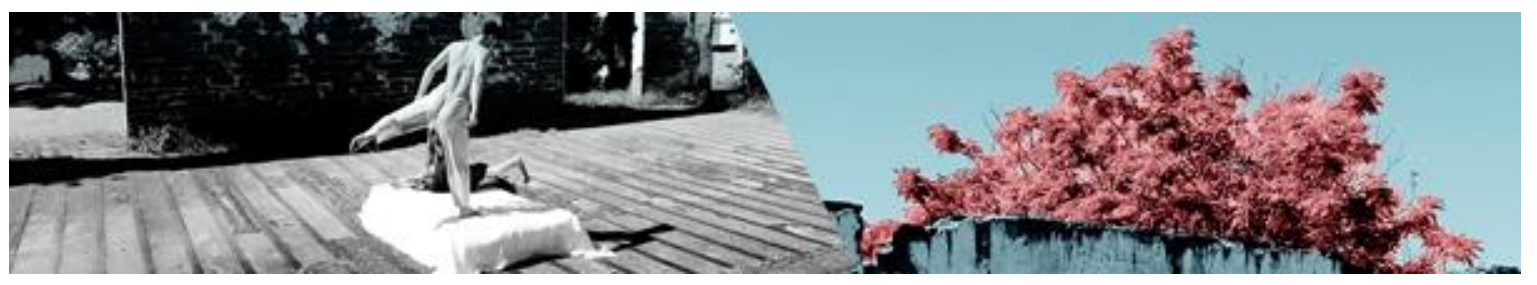

dança, existe uma artificialidade latente; tão latente como as repetições que ela rubrica, ou quanto os caminhos de idas e vindas, entre perguntas respondidas e respostas perguntadas aos seus bailarinos-intérpretes, ao início de cada trabalho, a partir de: 25 bailarinos; 12 apresentações de 1977 a 1985, na Europa, Ásia e América do Norte. A única música, em 1h e 50 min de duração do espetáculo, é de Béla Bartók ${ }^{9}$ que a compôs em 1911; o espaço tem o chão coberto de folhas nas quais as ações dos bailarinos-intérpretes deixam seus rastros e, cujos únicos objetos são: uma cadeira e um carrinho com um gravador, no qual a música é controlada por um dos intérpretes e reproduzida repetidamente em fragmentos.

A relevância desta obra, razão pela qual é abordada no presente artigo, parte do que coloca Katia Canton (1994, p.152-160):

A inauguração do Tanztheater corresponde especificamente à criação do Barba-Azul. Nessa obra Bausch criou pela primeira vez uma combinação de movimento, música e elementos teatrais que não era nem balé nem ópera. [...]não inclui palavras faladas no palco; Bausch começou a utilizar sistematicamente as palavras só depois desta peça.

BARBA-AZUL (1977)

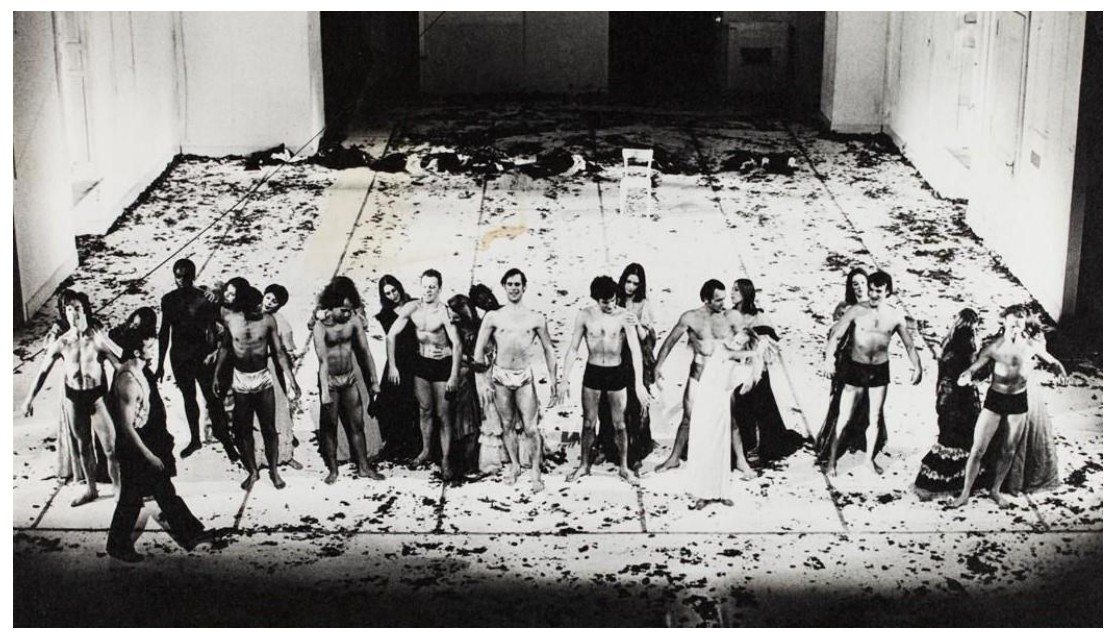

Vinte e cinco ${ }^{10}$

\footnotetext{
9 Béla Bartók (1881-1945): músico húngaro que compôs O Castelo de Barba-Azul, ópera em um ato, inspirado pelo conto Barba-Azul, de Charles Perrault.

10 http://www.pina-

bausch.de/fileadmin/_processed_/3/c/csm_Ulli_Weiss_blau_30022554_50_0000_500_Kopie_fc0136e79c.jpg
}

BRUÇO, Rita. Pina: quando a dança pode romper o discurso. Revista da FUNDARTE, Montenegro, p.340-357, ano 19, no 37, Janeiro/Março.

Disponível em: http://.seer.fundarte.rs.gov.br/index.php/RevistadaFundarte/index> 30 de março de 2019. 


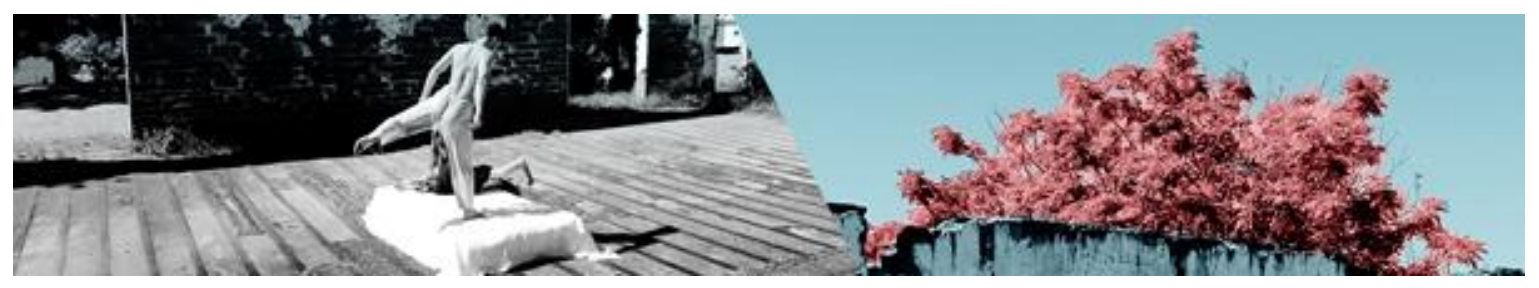

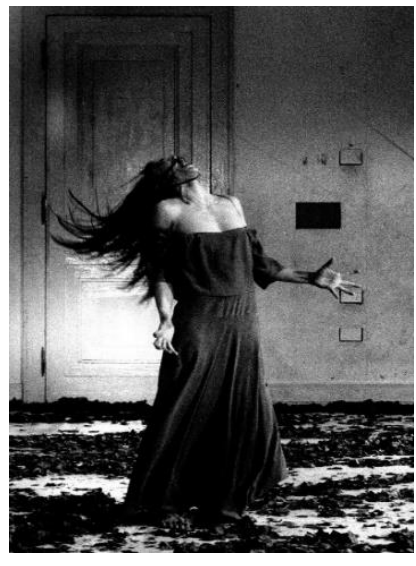

$U m^{11}$

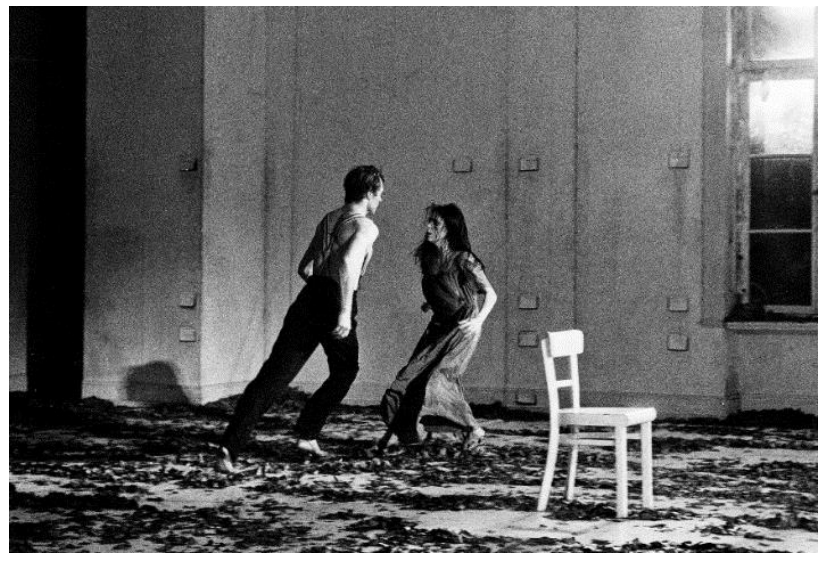

Dois $^{12}$

A escolha do Barba-Azul como tema, teve relação com o seu desejo de "lidar não apenas com o desespero de Judith (o nome dado por Bartók à mulher do BarbaAzul), mas também à profunda solidão do próprio Barba-Azul"13 (CANTON, 1999, p. 162-163). Já na forma como se refere ao que a teria motivado para trazer um conto de fadas ao palco, Pina Bausch revela o seu olhar sobre o conto de autoria de Charles Perrault, poeta francês do século XVI, que tem algumas de suas obras, como Bela Adormecida e Cinderela, encenadas, ainda hoje, por companhias e escolas de ballet no mundo todo. Vale lembrar que a estrutura narrativa destas encenações, o que consta no libreto é, em sua maioria - senão em totalidade - tal qual a versão do conto de Perrault. Com este deslocamento de interesse sobre o conto, verifica-se, como coloca Canton (1994, p.150-151):

Embora tenha utilizado o conto de Perrault como fonte [...] Em Bausch, o que é reforçado não é o motivo do quarto proibido ou a lição de moral especialmente destinada às mulheres. [...] aproveita o tema central do Barba-Azul, o de um homem que se casa com uma mulher e exercita o seu poder destrutivo sobre ela, e o reelabora em cenas episódicas que exibem as emoções mais pungentes e frequentemente ambivalentes que cercam a relação entre este homem e a mulher. [...] não está interessada na trama do

\footnotetext{
11 http://www.pina-bausch.de/fileadmin/user_upload/photo_maarten_vanden_abeele.72_resized-18_Kopie.jpg

12 http://www.pina-bausch.de/fileadmin/user_upload/photo_maarten_vanden_abeele.72_resized-20_Kopie.jpg

13 Palavras de Pina Bausch em entrevista à Katia Canton (1994) em 19 nov. 1991.
} 2019. 


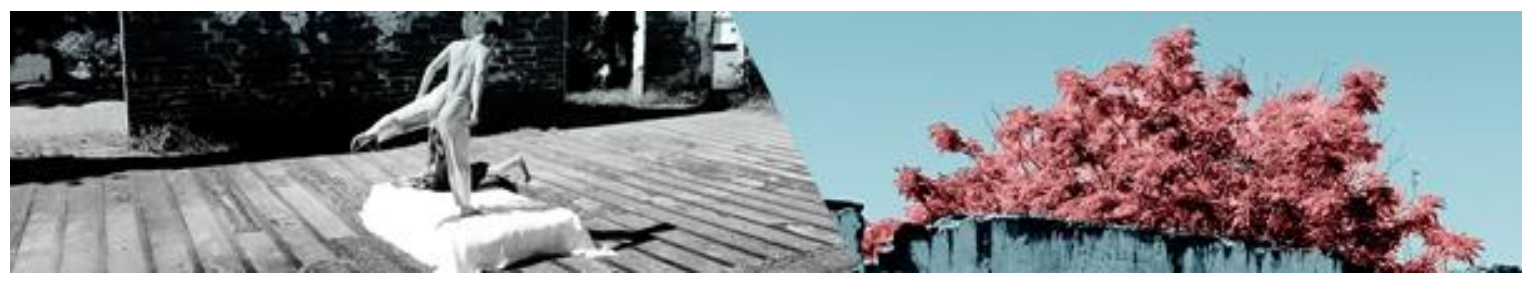

conto. Em Bausch, a narrativa fatual é substituída inteiramente pela narração absurda de emoções. O texto dá lugar ao subtexto.

É um subtexto que emerge em perguntas. As perguntas de Pina, que podem ser um tema, uma palavra, uma situação, um som (etc) começam o processo de criação numa imersão em conversa com os bailarinos-intérpretes. Um, dois meses, até que o que foi obtido é revisitado, num universo de uma centena de motes de partida (frases, pequenas cenas); só então ela parte para uma forma estética, a qual era objeto de uma importante busca para Bausch. (HOGHES, 1989) Uma forma, em Barba-Azul, como descreve Katia Canton (1994, p.168-169):

O dinheiro do Barba-Azul, presente na história de Perrault e no libreto de Bartók, é sugerido aqui pela imagem do poder de manipular o toca-fitas [...] a fita adquire múltiplos papéis durante a peça. Às vezes desempenha o papel de um narrador externo, observando e julgando as personagens. Outras vezes, parece personificar emoções, como a curiosidade, a opressão, o medo. [...] A violência com a qual ele pula continuamente sobre a mulher e a arrasta pelo chão sugere estupro, ao qual ela acaba não oferecendo resistência. Aqui o estupro substitui o assassinato das duas outras versões. [...]A passividade da mulher ao estupro se dissolve em afeição quando ela, a seguir, o abraça em resposta. Esse tipo de interação ambígua revela a natureza contraditória das emoções e dos papéis sociais. A mulher é a vítima, mas ela usa essa condição como arma. O homem é o dominador e o vitorioso, mas, ao mesmo tempo, é prisioneiro de sua própria autoimagem. [...]Imagens de solidão, violência e exploração adquirem força através da manipulação de grandes multidões de intérpretes. Neste caso eles não funcionam como intérpretes, mas como ressonâncias de estados emocionais, derivadas da essência do relacionamento entre Barba-Azul e Judith.

Ressonâncias, reverberações, fragmentos exagerados, sequências de repetição... Mesmo sendo uma das características mais conhecidas de Pina, é importante dizer que repetir era repetir. Não era acumular, nem reordenar. Havia uma certa circularidade no fluxo de suas composições, onde o tempo era estendido em movimentos conhecidos, como se o espectador pudesse, durante isso, acomodar o que já sabia (porque era repetido), tendo meios de entrar ou sair daquele estado provocado pelas sequências. Não apenas o espectador, mas o bailarino-intérprete, ao repetir, tinha seu estado inicial alterado e, talvez, revelar 0 "depois" de um "antes" com um "durante" intenso, fosse a "nudez" praticada por Pina

BRUÇO, Rita. Pina: quando a dança pode romper o discurso. Revista da FUNDARTE, Montenegro, p.340-357, ano 19, no 37, Janeiro/Março.

Disponível em: http://.seer.fundarte.rs.gov.br/index.php/RevistadaFundarte/index> 30 de março de 2019. 


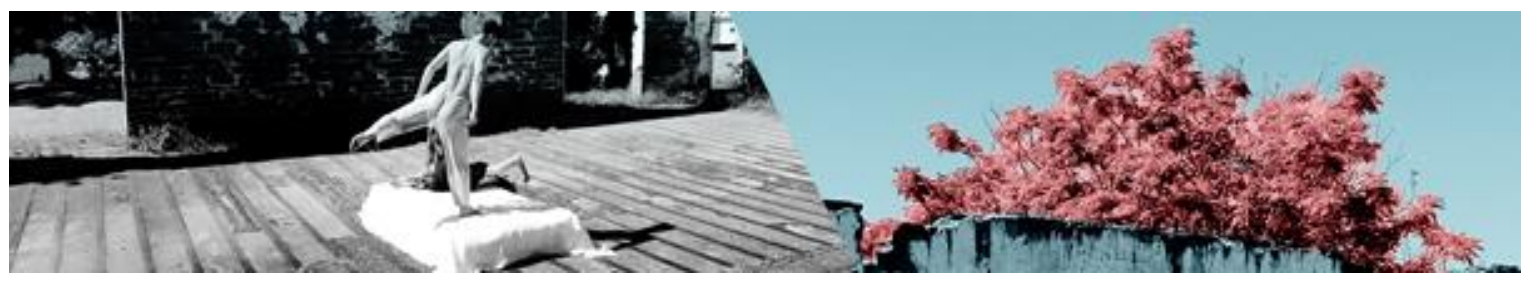

Bausch. Uma nudez que revela o óbvio e, que por óbvio, não se percebe. Em BarbaAzul, reconhecido conto transformado em ópera, cuja moral não era favorável às mulheres, Pina traz uma abordagem que não é favorável a ninguém, como nota Canton (1994, p.173):

[...]A solidão está no centro da visão de Bausch do conto. É uma solidão que se aplica tanto às mulheres quanto aos homens, já que elas são oprimidas, como vítimas e eles precisam lutar a fim de manter sua imagem de força. Essa solidão é mostrada abstratamente por gestos e, às vezes, é representada pelo uso de acessórios, como, por exemplo, uma boneca de plástico.

À mostra estava também a total despreocupação de Pina em recontar a história ou em resolvê-la ao modo como os contos são narrados, onde o bem vence o mal e todos são felizes para sempre. Pina cria camadas. De folhas, de roupas, de movimentos e de sonoridades que projetam uma investigação sobre a essência. Revela encobrindo, descobre revelando. Seu interesse se concentra particularmente sobre o "mito" ou artefato cultural, por que ele proporciona ao coreógrafo material importante sobre o efeito desumanizante dos clichês e das convenções sociais. (CANTON, 1994, p. 182)

Judith, morre depois de ser violentamente jogada de um lado para o outro por Barba-Azul que, como um clichê, desaparece em cena. O espaço escurece até que ele não possa mais ser visto. Bailarinos-intérpretes repetem movimentos ao som de palmas, cuja cadência diminui até cessar e, com aqueles corpos imóveis, como que vazios de reverberação, o espetáculo termina.

\section{DO DISCURSO DE PINA EM BARBA-AZUL}

A materialidade dos corpos em Barba-Azul é inegável. As imagens trazidas foram meramente ilustrativas, pois a dança é uma arte do espetáculo vivo, mesmo em vídeo, muito se perde, pois o "para onde devemos olhar" é direcionado em sua edição. Embora tenha sido possível ter um olhar curioso no vídeo analisado 


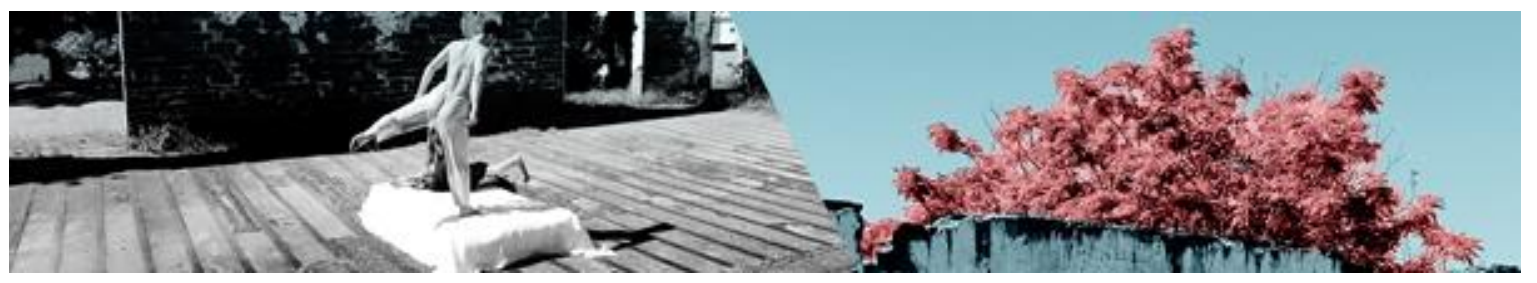

(BARBA-AZUL, 1997), infelizmente, esta obra não está em turnê desde 1985 e não temos como saber qual seria a recepção do público hoje.

Que os contos de fada permeiam o imaginário e a indústria do entretenimento, disso sabemos e as razões para tanto, que são objeto de estudo aprofundado, não nos interessa recepcionar aqui. Mas, já que a obra foi inspirada num conto, cumpre ressaltar que dele se extraíram e ainda se extraem lições que são visíveis e, pasmem, ainda vigentes em nossa sociedade. E estamos falando de idos do século XVII; à época dos contos, onde a sexualidade tabu, à qual nos referimos, talvez pudesse ser lida como uma "sexualização" das relações, referindo ao conceito de sexo como o biológico, a papéis definidos por ele e a todo o equívoco letal (em muitos casos) de uma visão de mundo antes dos movimentos feministas terem "forçado a porta" e tensionado as relações em uma sociedade patriarcal e machista, três séculos depois. Em 1977, quando Pina pôs Judith no palco, o ocidente também era chacoalhado pelo que viria a ser conhecido como um dos aspectos construídos socialmente, que nada mais é, hoje, àquilo que denominamos como representações de gênero. Aqui também não queremos adentrar neste lugar tão fecundo e diverso, respeitando tudo que podemos manifestar em aporte argumentativo, porque muitos e muitas se debruçaram para que possamos fazê-lo e para que tenhamos evoluído nestes séculos todos. Mas, cabe sim colocar que, na presença daqueles corpos ou de quaisquer corpos, ocorre o que refere Ciane Fernandes (2007, p. 30):

É através da imagem corporal que o esquema de gestos e posturas de uma sociedade é transmitido. A identidade corporal individual não é autêntica nem contrastante à sociedade. $\mathrm{O}$ corpo individual é um corpo social - uma construção a nível psíco-físico, constantemente permeada e controlada por repetitivas normas de disciplina em meio a relações sociais de poder.

Pina manteve a identificação de gênero correspondente ao sexo, na escolha do figurino e na escolha da temporalidade (quando os movimentos eram executados) e espacialidade (onde e por quem eram executados). Por exemplo, só

BRUÇO, Rita. Pina: quando a dança pode romper o discurso. Revista da FUNDARTE, Montenegro, p.340-357, ano 19, ํo 37, Janeiro/Março.

Disponível em: http://.seer.fundarte.rs.gov.br/index.php/RevistadaFundarte/index> 30 de março de 2019. 


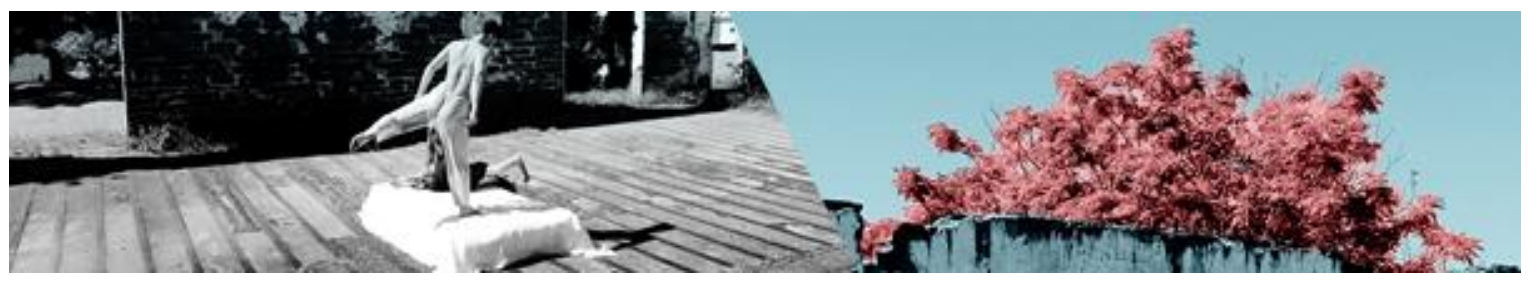

as mulheres foram oferecidas ao Barba-Azul e só os homens mostraram seus corpos ostentando uma virilidade à Judith. Como Pina entrelaça ação e reação como um encadeamento perscrutante, não se pode perceber uma simetria tonal de gênero, como se as mulheres só reverberassem Judith e os homens Barba-Azul, uma vez que o elenco ressoava emoções. Não é assim tão simples como sombras estáticas. Há um sombreamento que é borrado quando as condições são levadas ao extremo e não se percebe, senão, solidões acompanhadas. Não se sabe ao certo porque, mas como em Pina, cada movimento mínimo conta; não deve ter sido em vão que a escolha do que poderíamos chamar de protagonistas, foi de Jan Minarik para Barba-Azul, um bailarino-intérprete visivelmente grande em relação aos demais e de Beatrice Libornati ${ }^{14}$ uma italiana muito franzina em relação a Barba-Azul. A força física, característica dada como de superioridade do homem em relação à mulher, estava ali evidenciada e foi, inclusive, pelo uso dela que Judith morre. Pina não nega que há diferenças entre homens e mulheres, não torna a mulher heroína ou a emancipa da sua condição de dominação, muito pelo contrário, revela a manipulação, o que poderia ser um poder diante da submissão. Não condena BarbaAzul, o faz esvanecer num palco, sem nenhuma glória ou tremendo castigo e faz ecoar cada violência, inclusive a que todos estavam à mercê: do abandono de si, quando existem papéis determinados. $O$ indivíduo e a sociedade formam uma unidade de interações (SERVOS, 2001, p. 34)

$\mathrm{E}$ quando Bausch interage com esta unidade, por meio de escolhas deliberadas sobre o que e como colocar em cena, o discurso/movimento é este: esta relação acaba assim. Observe que, nesta realidade, também neste palco, nos violentamos e estamos fadados a repetir isso, como repito aqui. Trouxe folhas secas, desnaturalizando aquilo que naturalizamos, colocamos o poder a ecoar num rádio para que todos ouvissem, e dançamos ao seu som, em silêncio e ao som dos

\footnotetext{
${ }^{14}$ Informação obtida na publicação de Katia Canton (1994), apesar deste nome não constar do elenco no release da obra no site da companhia (http://www.pina-bausch.de/en/works/completeworks/show/blaubart-beim-anhoeren-einer-tonbandaufnahme-von-bela-bartoks-oper-herzogblaubarts-burg/).
}

BRUÇO, Rita. Pina: quando a dança pode romper o discurso. Revista da FUNDARTE, Montenegro, p.340-357, ano 19, ํo 37, Janeiro/Março.

Disponível em: http://.seer.fundarte.rs.gov.br/index.php/RevistadaFundarte/index> 30 de março de 2019. 


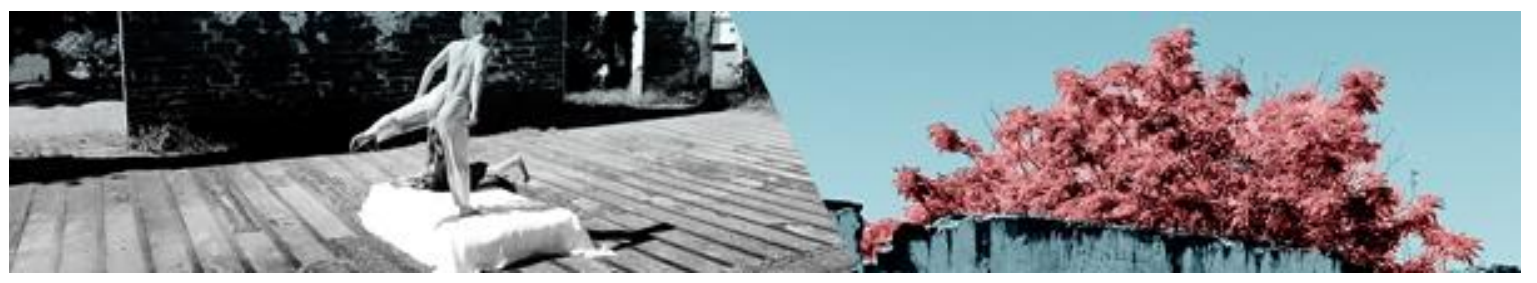

aplausos de aceitação, tímidos em palmas, até que nada mais nos movesse. - É o que se poderia ouvir/ver quando a cortina fecha. Como traz José Gil (2001, p. 220):

O "performativo", o "ilocutório" não fariam parte justamente dessas ações implicadas por qualquer fala, "pressupostos implícitos e não discursivos" de todo discurso? O "método Bausch" reduzir-se-ia a uma atenção particular concedida ao ilocutório de qualquer discurso... e à sua transformação em gestos "performativos". Ou ainda, os seus gestos nada seriam além dos "atos" que acompanham qualquer fala. [...]visa a transformação de imagens artísticas e não, como uma experiência da linguística, a detecção e a transformação do ilocutório em "atos de fala". O que torna tudo diferente.

Pina Bausch difere porque fala desse lugar, do que sempre esteve implícito, dado em saberes, posto pelas instituições e absorvido socialmente naquilo que se reconhece e, assim, se estabelece. Difere em sua prática discursiva porque, em suas idas e vindas, seus fragmentos e repetições, quebra a regularidade com que se percebe o conjunto de enunciados discursivos e evoca um outro sistema de locução: em movimento. E por meio disso, Pina Bausch é a sua dança-teatro.

\section{DA PRESENÇA DE PINA NA DANÇA-TEATRO OU QUANDO A DANÇA PODE ROMPER ${ }^{15}$ O DISCURSO}

Tô te explicando

Prá te confundir

Tô te confundindo

Prá te esclarecer

(TOM ZÉ, 1975)

Isso é quase sempre o que ocorre quando se tenta responder, de forma sucinta, o que é dança-teatro. O que mais comumente se ouve, e só sabe disso quem pergunta, é o que ela não é: comum, ainda que seja definida com traços da contemporaneidade em dança. Sobretudo, ouve-se um aparato histórico que

\footnotetext{
15 Intencionalmente, neste momento, se revela o sentido do verbo transitivo direto romper: penetrar, passar para o interior, permear.
}

BRUÇO, Rita. Pina: quando a dança pode romper o discurso. Revista da FUNDARTE, Montenegro, p.340-357, ano 19, ํo 37, Janeiro/Março.

Disponível em: http://.seer.fundarte.rs.gov.br/index.php/RevistadaFundarte/index> 30 de março de 2019. 


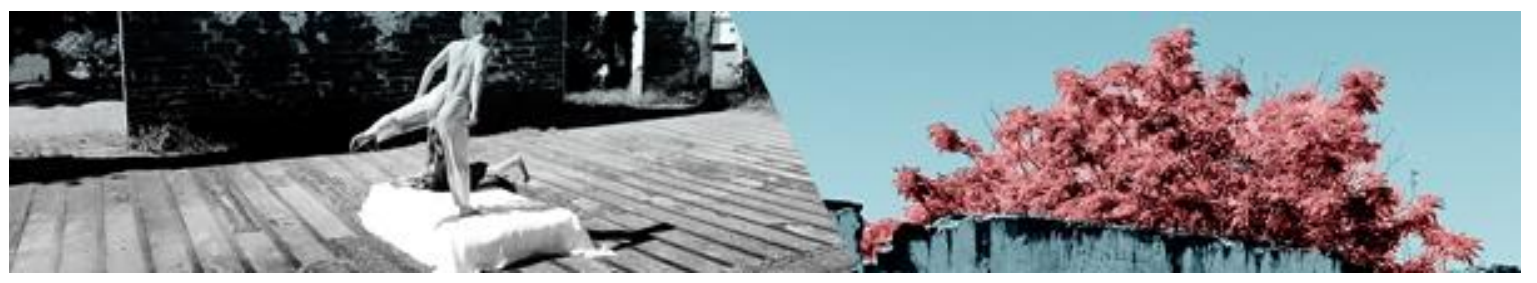

traciona a resposta em anos de segundos, fazendo uma verticalidade cronológica da dança ocidental que, em minutos, acaba na Alemanha e em todos que vieram antes, mas, invariavelmente, em Pina. E a atração que ela exerce é por décadas de produções riquíssimas em tudo o que, felizmente, ninguém conseguiu explicar em palavras, pormenorizadamente, o que é, sem que isso batesse em alguma teoria condicionante do que não é. E por isso, muito ainda se escreve e há de se escrever sobre ela, mesmo com as estruturas do discurso tentando colocar a arte neste lugar menor em relação às outras áreas do saber, ou ainda, fazendo com que quem escreva, cumpra determinados pressupostos do que é tido como "rigor científico", como se a arte não fosse exatamente um meio pelo qual os rigores podem ser flexibilizados. Enfim, é possível que se delimite o assunto, intentando responder uma questão e se persiga determinadas hipóteses e se discorra sobre isso.

Ciane Fernandes (2007) aqui representa esse tanto de gente da dança que entende a diferença do "em dança" e do "na dança" e se lança num "fora" que acaba dentro, na sua prática, no seu corpo. É o que pesquisadores em dança fazem. Afora o tempo, muitas vezes solitário, em que se afastam do encontro com os seus e com outros corpos, enquanto realizam a árdua tarefa de escrever e realizar o encontro daquilo que este artigo trata: linguagem, comunicação e discurso. Não se trata de nenhuma tentativa de validar esta ou aquela área e, sim, um indicativo para quem pretende se lançar neste mundo fonético percorrendo o caminho pelo corpo: indicativo 1 de rompimento.

A partir da linguagem que se classifica até aqui, demonstra-se claramente que a dança-teatro de Pina Bausch é uma técnica em dança (MAUSS, 2003), pois não há como um corpo não ser modificado, quando colocado em contato com um processo que o modifica, mesmo que o processo seja, como no caso, de dentro para fora. As possibilidades articuladas de movimento e não codificadas (entendendo por código aquilo que pode ser reproduzido em igual forma, sem adentrar no mérito singular, e nominado de forma idêntica, para que possa ser compreendido por quem

BRUÇO, Rita. Pina: quando a dança pode romper o discurso. Revista da FUNDARTE, Montenegro, p.340-357, ano 19, no 37, Janeiro/Março.

Disponível em: http://.seer.fundarte.rs.gov.br/index.php/RevistadaFundarte/index> 30 de março de 2019. 


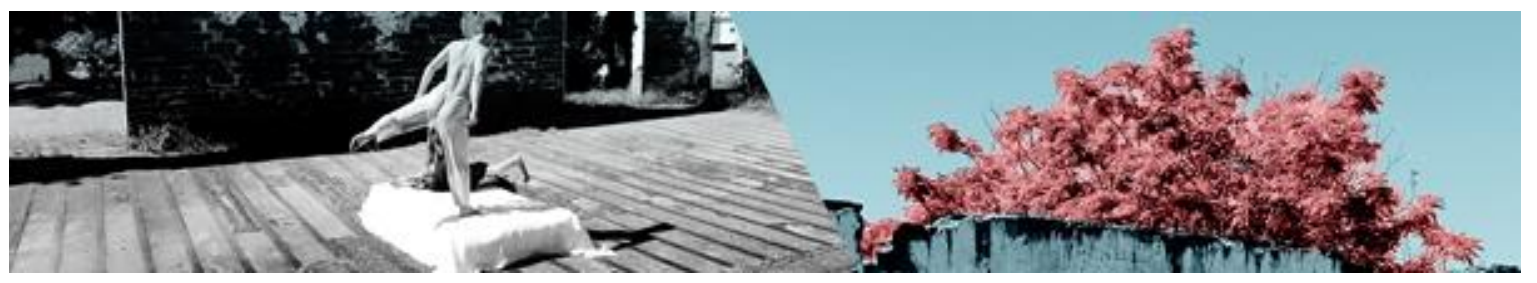

pretende executá-lo) produzem tanta reverberação no corpo do bailarino-intérprete, modificando-o, como quem realiza pliés como movimento executado numa prática de ballet. Apenas exemplificando, pois aqui também não interessa nenhuma classificação, cada técnica que o corpo pode experimentar, desde a considerada mais rudimentar e inominada, até a mais específica (para não confundir com virtuosa) e apurada em terminologias, será tornada ação-palavra (GIL, 2001) em dança-teatro: indicativo 2 de rompimento.

A partir do que escreve Ciane Fernandes (2007, p. 34):

Dentro deste dilema corpo-mente, movimento-palavra, as interpretações, naturalista ou linguista, favorecem um ou outro lado, ao invés de explorar criticamente a relação de poder e a constante e recíproca influência entre palavras e movimentos, seja em dança, seja na vida cotidiana. Uma teoria que questione estas relações de poder requer uma redefinição de "linguagem" além do puramente verbal. Esta teoria incluiria a maior das contradições da dança - sua fisicalidade real como um sistema de signos abstratos - sem impor uma unidade artificial e uma verdade final.

Há uma fisicalidade que Pina Bausch imprimia entre idas e vindas em seu processo: começava pela palavra, que ganhava forma no corpo e que produzia imagens em cena - um trajeto não linear que, aparentemente, pretendia retirar a carga semântica que as palavras evocam, principalmente, quando são motes de movimento. $O$ corpo acaba por realizar uma sintaxe idêntica. Ao revisitar várias vezes as palavras, nos meses que antecedem a procura pela forma, dando proposições, a priori não relacionadas aos bailarinos-intérpretes a impressão no corpo em cada um/uma à palavra "solidão", por exemplo, adquire outro léxico corporal. O questionamento "O que você faz quando ninguém está olhando?" remete a uma outra forma de solidão e possibilita novas formas de acesso a movimentos menos carregados do padrão emocional das palavras - padrão subvertido em singularidade. Pina Bausch explorava a ordem palavramovimento/movimento-palavra, para que o corpo fosse imperativo na narrativa de sua história: indicativo 3 de rompimento.

BRUÇO, Rita. Pina: quando a dança pode romper o discurso. Revista da FUNDARTE, Montenegro, p.340-357, ano 19, no 37, Janeiro/Março.

Disponível em: http://.seer.fundarte.rs.gov.br/index.php/RevistadaFundarte/index> 30 de março de 2019. 


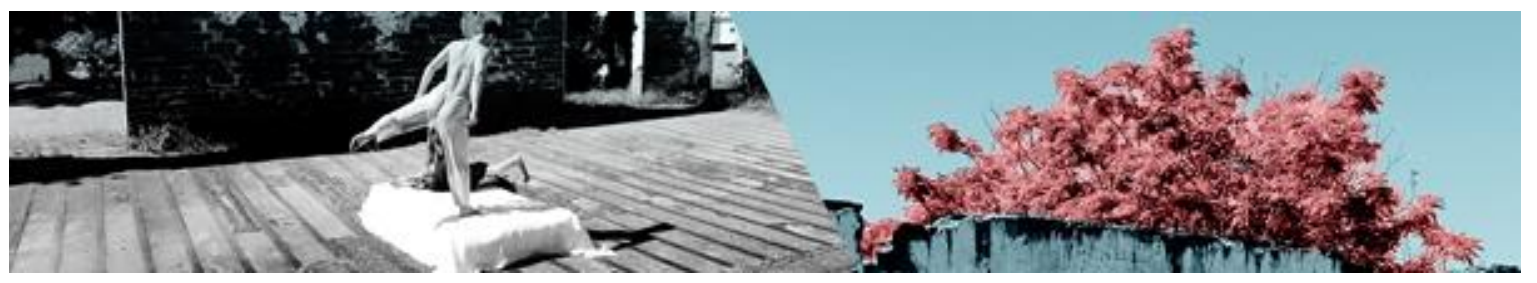

À percepção da obra de Bausch ou das que estão disponíveis, como BarbaAzul, nota-se a possibilidade de experienciar suas distensões de tempo, suas relações em formas estéticas, o uso da vocalização de palavras (como ocorre em obras subsequentes a esta trazida), o perfil de seus bailarinos-intérpretes múltiplos e diversos, corporal e culturalmente, etc. Vale ressaltar aqui um adendo de interesse: em 2000, Pina remontou Kontakthof traduzido em "Pátio de contatos" (HOGHES, 1989) com bailarinos-intérpretes "seniores", trazendo à cena corpos que não são cotidianamente vistos nela. Tudo isso são formas, ainda que parciais, de ter acesso a uma técnica em dança tão ligada à subjetividade de Pina, como quem adentra num grande vocabulário do qual se pode partir para construir uma linguagem própria, o que se pretende neste artigo; linguagem esta capaz de levar em consideração que toda a obra em dança é também discurso. Sob este aspecto: Quais discursos validamos? Como nos colocamos, enquanto artistas, não apenas para criar imagens e sensações, mas como percebemos o mundo para que possamos permitir outras formas de olhar e sentir? Nada do que fora trazido neste artigo teria propósito, se não tivéssemos fonemas disponíveis para elencar num enunciado e, se por meio deles, não validássemos discursos que possam modificar o estabelecido, como pretendemos. Uma concordância que, Pina Bausch, como ninguém, realizou.

\section{Referências:}

BARBA-AZUL. Pina Bausch. Alemanha, 1977. Disponível em: < http://www.youtube.com/watch?v=C31aUjxHPYY\&t=2s>. Acesso em: 02 mar. 2018.

CANTON, Katia. E o príncipe dançou... O conto de fadas, da tradição oral à dança contemporânea; tradução: Cláudia Sant'Ana Martins. São Paulo: Ática, 1994.

FERNANDES, Ciane. Pina Bausch e o Wuppertal dança-teatro: repetição e transformação. São Paulo, Annablume 2007. 


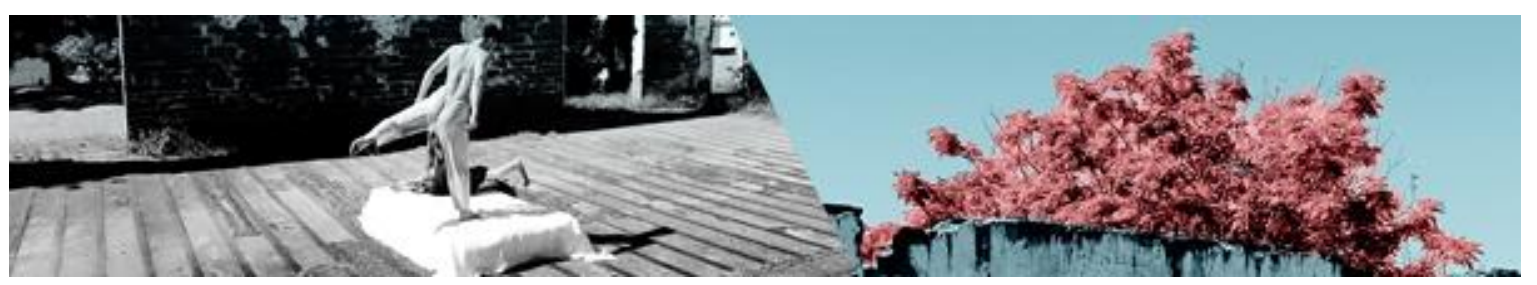

FOUCAULT, Michel. A ordem do discurso: aula inaugural no Collège de Frances, pronunciada em 2 de dezembro de 1970; tradução: Laura Fraga de Almeida Sampaio. São Paulo: Loyola, 1999.

A arqueologia do saber, tradução: Luiz Felipe Baeta Neves. 7. ed. Rio de Janeiro: Forense Universitária, 2008.

GIL, José. Movimento total: o corpo e a dança; tradução: Miguel Serras Pereira. Lisboa: Relógio D’Água, 2001.

GUMBRECHT, Hans Ulrich. O campo não hermenêutico ou a materialidade da comunicação; tradução: João Cezar de Castro Rocha. Teresa, São Paulo, n. 10-11, 2010, p. 388-409. Disponível em: <http://www.revistas.usp.br/teresa/article/view/116873/114412>. Acesso em: 26 set. 2018.

A presença realizada na linguagem: com atenção especial para a presença do passado; tradução: Bruno Diniz e Juliana Jardim de Oliveira e Oliveira; revisão técnica: Valdei Araujo. História da Historiografia, Ouro Preto, n. 3, 2009, p. 10-22. Disponível em: $<$ http://www.historiadahistoriografia.com.br/revista/article/view/68/30>. Acesso em: 02 out. 2018.

HOGHES, Raimund; WEISS, Ulli; tradução: Robson Ribeiro e Gaby Kirsch. Bandoneon - Em que o tango pode ser bom para tudo?. São Paulo: Attar, 1989.

MAUSS, Marcel. As técnicas do corpo. In: tradução: Paulo Neves. São Paulo: Cosac \& Naify, 2003. Sociologia e Antropologia;

SERVOS, Norbert. Pina Bausch ou l'Art de dresser un poisson rouge. Paris: L'Arché 2001;

SPARSHOTT, Francis. A measured pace: toward a philosophical understanding of the arts of dance. Toronto: University of Toronto Press, 1995.

ZÉ, Tom. Tô. In: Estudando o samba. [S.I.]: Warner Music Brasil, 1975. 1 disco sonoro. 


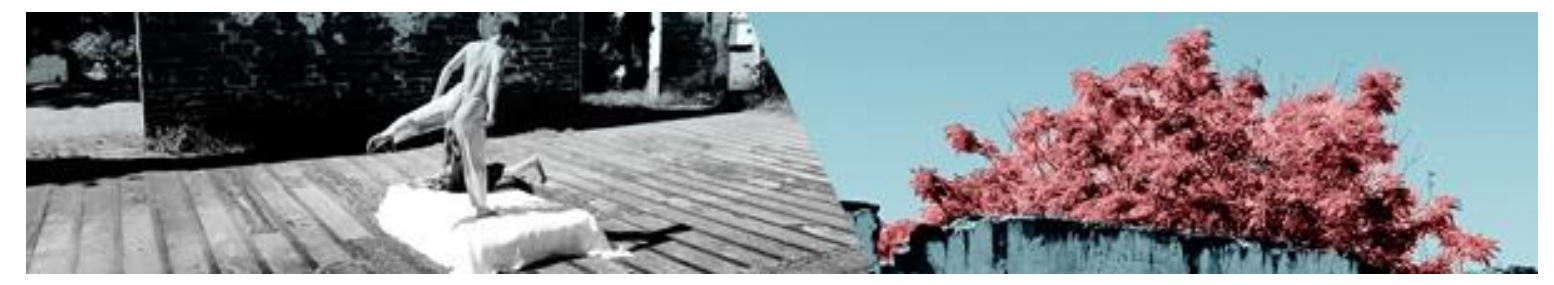

\section{Agradecimento}

Pela disponibilidade, comprometimento e diligência de duas professoras do curso de Graduação em Dança: Licenciatura da Universidade Estadual do Rio Grande do Sul, que - em pleno período de férias - emprestaram seu olhar atento, sensível e técnico a este trabalho.

Gratidão, Kátia Salib Deffaci e Aline da Silva Pinto. 